\title{
Sciendo
}

Administration, vol. 69, no. 1 (2021), pp. 85-95

doi: 10.2478/admin-2021-0007

\section{State-owned enterprise sector, 2020}

\author{
Dónal Palcic \& Eoin Reeves* \\ Department of Economics, Kemmy Business School, \\ University of Limerick, Ireland
}

\section{Overview $^{1}$}

While the Covid-19 pandemic has had a significant negative impact on the overall Irish economy, the severity of the impact on individual firms very much depends on the sector in which they operate. Stateowned enterprises (SOEs) in the aviation and public transport sectors have therefore experienced the most severe impact in 2020, with companies operating in the energy and communications sectors not affected to the same extent. The true extent of the impact of the pandemic on the financial performance of the SOE sector will not become apparent until annual reports are published next year, and the degree to which government support may be required for some companies will depend on how quickly Covid-19-related restrictions can be eased in 2021.

Table 1 provides an overview of the basic financial performance of the main Irish SOEs for the 2019 financial year. As highlighted in recent reviews (Palcic \& Reeves, 2018, 2019, 2020), the commercial SOE sector continues to make an appreciable contribution to the Irish economy, with aggregate turnover for the thirteen companies included in Table 1 equivalent to approximately 4.7 per cent of nominal

* ORCID: Dónal Palcic - http://orcid.org/0000-0003-4726-9640; Eoin Reeves http://orcid.org/0000-0003-4674-3152

1 The analysis and discussion presented in this review rely heavily on information provided in SOE annual reports and on SOE websites. 


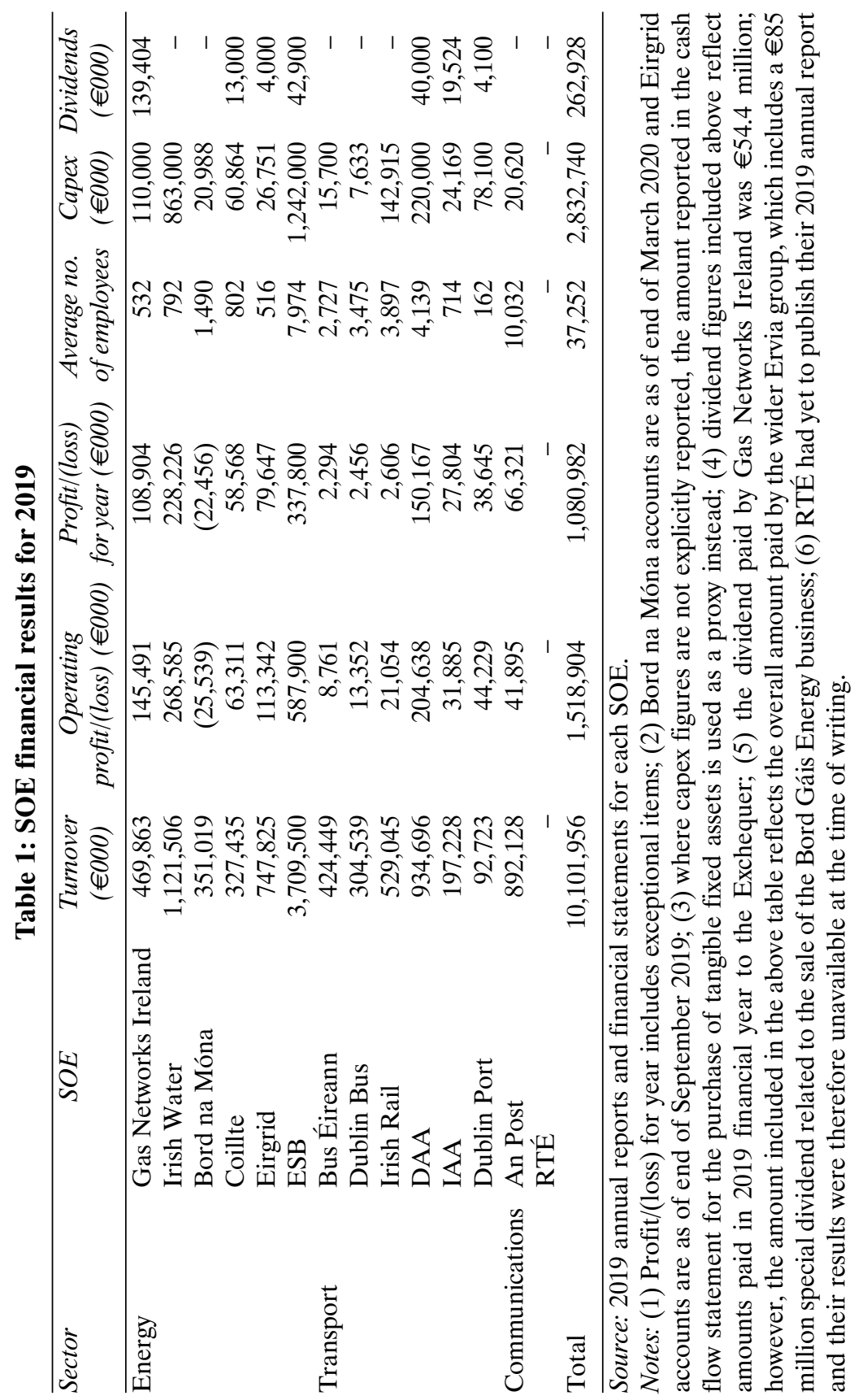


modified gross national income (GNI*) in 2019, and aggregate employment of over 37,000 people. The commercial SOE sector also plays a vital role in delivering much needed investment in public infrastructure, with over $€ 2.8$ billion in aggregate capital expenditure invested by the SOEs included in Table 1 in 2019. In addition, seven SOEs contributed almost $€ 263$ million in dividends to the Exchequer in 2019, bringing the total amount paid by the SOEs included in Table 1 between 2008 and 2019 to over $€ 3.1$ billion. $^{2}$

Bord na Móna (BnM) was the only SOE in Table 1 to report a net loss for 2019, largely as a result of continued exceptional restructuring costs related to its transition away from traditional peat-related activities. However, there are a number of SOEs that are facing underlying challenges that will affect their future performance, with Brexit and the impact of the Covid-19 pandemic affecting each SOE to varying degrees. The next section provides a brief summary of some of the main developments in 2020 across individual SOEs.

\section{Bord na Móna}

BnM continued to incur significant losses in the 2019/20 financial year, recording an operating loss of $€ 25.5$ million and a net loss of $€ 22.5$ million. While both of these figures were less than half of the record losses experienced in the previous year, the company is continuing to struggle with the cost of its 'brown to green' transition away from traditional peat-related activities. Exceptional costs related to this restructuring amounted to $€ 65.9$ million in 2019 , which, on top of the $€ 91.4$ million in exceptional costs incurred during the previous year, demonstrate the significant efforts being made by the company to move towards a revenue model based on lower carbon activity.

In terms of underlying performance, turnover and operating profits before exceptional items were down slightly compared to 2018, largely due to reduced peat sales and the ending of coal sales as BnM exited this business. Peat sales will decline even further in 2020 as a result of the closure of the ESB's peat-burning plants at Shannonbridge and Lanesboro in Offaly in December 2020. While BnM is likely to continue to struggle financially in the short term as a result of its continued restructuring activities, the fruits of some of its transition efforts can already be seen in the $€ 4$ million profit generated by the

2 Source: authors' calculations based on figures included in Exchequer statements and SOE annual reports. 
company's joint ventures in 2019 , with the $€ 180$ million Oweninny wind farm in Mayo (a joint venture with the ESB) commencing operations in October 2019. BnM has also begun constructing a $€ 100$ million wind farm at Cloncreen in Offaly, after it successfully bid for $158 \mathrm{MW}$ of capacity in the government's new Renewable Energy Support Scheme auction held in September 2020, which also covers the second phase of its Oweninny wind farm joint venture with the ESB (Gleeson, 2020).

\section{An Post}

An Post's turnaround continued in 2019 with a third successive year of profits, a stark contrast to its situation in 2016 when it was one of the biggest loss-makers in the SOE portfolio. Operating profits in 2019 stood at $€ 41.9$ million, with the company reporting net profits for the year of $€ 66.3$ million due to exceptional profits of $€ 40$ million related to the disposal of An Post's share in the One4All Gift Voucher group of companies in January 2019. Despite a further 6.3 per cent decline in traditional mail volume, reflecting a continued international trend in recent years, An Post's turnover increased 2 per cent on the back of significant growth in packets and parcel volumes.

An Post's 2020 performance looks set to be relatively unscathed by Covid-19 due to a surge in parcel volumes as a result of increased online shopping during the pandemic. In December 2020 alone, An Post delivered 14 million parcels, which was double the number delivered during the same month in 2019. Overall, parcel volumes in 2020 were up 100 per cent while traditional mail volume declined a further 10 per cent, with An Post announcing plans to invest over $€ 100$ million in new infrastructure over the next three years to help it deal with the move towards a business dominated by parcel delivery (Hancock, 2021). An Post also played, and continues to play, a major role during the pandemic by providing a lifeline for many people in both urban and rural areas during lockdown periods by offering a 'check-in' service, as well as delivering newspapers free of charge to elderly or vulnerable customers forced to cocoon (Wall, 2020).

\section{Dublin Airport Authority}

In 2019 the Dublin Airport Authority (DAA) recorded further improvements across all of the main financial performance indicators, following a trend of sustained year-on-year growth since 2015. As in 
previous years, the company set a new record in terms of passenger numbers at Dublin Airport, with Cork Airport and the DAA's international duty free business also performing well. However, travel restrictions related to the Covid-19 pandemic decimated the DAA's business in 2020, with the company expecting total passenger numbers to fall from 35.5 million in 2019 to just 9 million in 2020, and to incur a loss of approximately $€ 200$ million (O'Halloran, 2020). In an effort to counteract the impact of Covid-19, the company has reduced its costs considerably through reduced working hours, voluntary redundancies, and pay and hiring freezes, while also borrowing $€ 500$ million through a bond issue in October 2020 to provide long-term liquidity for the company.

The Commission for Aviation Regulation's (CAR) decision in December 2019 to reduce passenger charges at Dublin Airport over the 2020-4 period has been appealed by the DAA, and the CAR has confirmed that it is reviewing its original price determination given the impact of the pandemic. The DAA announced in December 2020 that it was rolling out a discount scheme on its passenger charges for the March 2021 to March 2022 period. The scheme will see the DAA reduce its charges by half for any airline that carries 50 per cent of the passenger numbers flown in any quarter compared to the same quarter in 2019/20, with further discounts offered for airlines that carry an even higher percentage of passengers. The extent to which the DAA will be able to recover in 2021 will very much depend on the speed and effectiveness of vaccine rollouts across the world and how quickly air travel can recover.

\section{CIÉ Group - Bus Éireann, Iarnród Éireann and Dublin Bus}

Dublin Bus reported net profits of $€ 1.4$ million in 2019 compared to $€ 3.7$ million in 2018. This reduction was mainly attributable to the repayment of a subvention ( $€ 4.9$ million) to the National Transport Authority (NTA) following the completion of the 2014 Direct Contract Award. Dublin Bus reported a 1.1 per cent decrease in overall customer journeys in 2019, which was largely due to the loss of approximately 10 per cent of Public Service Obligation (PSO) routes in the new environment of greater market liberalisation that commenced in 2018. However, two new PSO routes were introduced and core PSO services grew by 5 per cent in 2019. In addition, the final design of the new bus network for Dublin, which is part of the NTA's 
'BusConnects' programme, was published in September 2020 and is expected to be implemented from 2021.

The financial performance of Bus Éireann improved as the company reported net profits of $€ 2.3$ million for 2019 , with passenger journeys (excluding schools) growing by 11 per cent. This marks a significant improvement in the financial performance of the company, which last returned a profit after exceptional items in 2013 and recorded losses of over $€ 23$ million in 2017. Iarnród Éireann reported record passenger numbers in 2019 following a 4.6 per cent increase on 2018 figures. This increase resulted in the company recording a surplus of $€ 2.6$ million compared to a loss of $€ 1.1$ million in the previous year. However, the company's accumulated losses remain extremely high (totalling $€ 152.7$ million at the end of 2019) and the company's solvency remains an issue for concern.

While the three transport companies within CIÉ performed relatively well in 2019, the public transport sector has been one of the hardest hit by the Covid-19 pandemic as people have travelled less frequently and social distancing requirements and health-related concerns have changed the type and pattern of travel for many. In addition, increased costs are being incurred due to factors including frequent cleaning, personal protective equipment for staff, perspex barriers, etc. The immediate impact of Covid-19 was highlighted by the Parliamentary Budget Office (2020), which estimated that passenger revenues for the three main public transport companies were reduced by approximately $€ 200$ million in Q2 2020 alone.

In the case of Bus Éireann, commercial Expressway services continued during the pandemic. However, as they ran at a financial loss due to Covid-19 restrictions, the company required liquidity support from its parent company, CIÉ, as well as increased PSO payments from the NTA. Several commercial services have been discontinued and it is planned to withdraw from four routes in 2021. The NTA and the Department of Transport also made additional funding available in order to ensure continuation of PSO services in 2020. Also, in 2021 Bus Éireann and Dublin Bus will operate under a gross contract PSO, under which the responsibility for revenues lies with the NTA and the company is paid for the cost of operating PSO services. This effectively reduces the demand risk held by both companies.

The pandemic had an immediate serious impact on the operations and performance of Dublin Bus, with commercial services suspended in April 2020. Although the business is projected to incur losses on commercial services and PSO services in 2020 and 2021, the company 
reported that its directors are satisfied that losses will be sustainable and that these losses can be funded from the company's resources as well as additional funding from the NTA and the Department of Transport. The performance improvements recorded by Iarnród Éireann in 2019 are set to be followed by a significant deterioration due to the impact of Covid-19 and the company projects it will incur losses on its commercial business in 2020 and 2021. Substantial reductions in passenger numbers will require an increase in the level of both NTA and wider Exchequer funding to meet costs in these years.

\section{ESB}

The ESB delivered improved financial results in 2019 following a decline in profitability in 2017 and 2018. Excluding exceptional items, operating profits increased to $€ 682$ million ( $€ 455$ million in 2018 ) and profit after tax increased to $€ 419$ million ( $€ 200$ million in 2018). When exceptional items (including a $€ 34$ million impairment charge relating to new Integrated Single Electricity Market rules) are included, profit after tax increased from $€ 60$ million to $€ 337.8$ million. The board recommended a final dividend of $€ 49.8$ million for 2019, which brings the total dividends paid by the ESB for 2019 to $€ 88$ million and to $€ 1.2$ billion over the last decade.

The company reported a gearing level of 57 per cent with net borrowings amounting to $€ 5.24$ billion ( $€ 4.92$ billion in 2018). In June 2019 the ESB successfully issued its inaugural Green Bond - the first public corporate green bond in Ireland. The $€ 500$ million bond was issued with a fixed coupon rate of 1.125 per cent. Overall, capital investment totalled $€ 1.24$ billion ( $€ 1.16$ billion in 2018), which included the acquisition of a 50 per cent stake in the 448 MW Neart na Gaoithe UK offshore wind farm project. This investment forms part of an overall strategy of significantly increasing the ESB's onshore and offshore wind portfolio. In addition, the company announced the cessation of electricity generation from peat by the end of 2020 and significantly rationalised the Moneypoint plant as part of the planned cessation of coal-fired generation by 2025 .

\section{Irish Water}

Irish Water is part of Ervia Group (along with Gas Networks Ireland and Aurora Telecom). As such, the company is overseen by the boards of both Ervia and Irish Water, and these arrangements will remain in 
place until Irish Water is established as a stand-alone, publicly owned, commercial, regulated utility in 2023. Irish Water reported profits before income tax of $€ 262$ million in 2019 (compared to $€ 157$ million in 2018). Higher revenues were attributable to increased government subvention revenue for the domestic sector, which was $€ 135$ million higher than the previous year. At the end of 2019, the company held total assets of just over $€ 3$ billion and its net debts stood at $€ 148$ million.

As part of its Capital Investment Plan, Irish Water is currently managing a portfolio of more than 400 capital projects and 40 national programmes. Total investment to date amounts to $€ 3.9$ billion ( $€ 863$ million capex in 2019) with a further investment of $€ 5$ billion planned up to 2024. The company faces several challenges in rolling out its significant programme of capital investment. A recent report by the Water Advisory Body ${ }^{3}$ outlines a number of deficiencies with the water and wastewater treatment systems that require prioritisation by Irish Water in the coming years. These include the needs to address non-compliance of wastewater treatment systems with EU directives; to demonstrate to the public that it is taking concrete actions to address the problem of leakage; and to ensure that Irish Water is adequately financed in order to deliver its capital investment programme (Water Advisory Body, 2020). In this context, it is important to recognise that the Covid-19 pandemic has led to delays in Irish Water's capital investment programme. Several projects have been suspended, which will have knock-on effects on the company's delivery timescales and higher costs associated with such delays.

\section{Gas Networks Ireland}

Gas Networks Ireland is a 100 per cent owned subsidiary of Ervia. It reported profits after tax of $€ 109$ million for 2019 (2018: $€ 123$ million). Revenue for the year was $€ 470$ million (2018: $€ 487$ million) and the company paid a dividend of $€ 54.4$ million (2018: $€ 49.1$ million) to the Exchequer during the financial year. In 2019 the company published Vision 2050, its strategy for the development of the gas network. The principal objective of the strategy is to contribute significantly to the decarbonisation of Ireland's energy sector. Specifically, the strategy aims to ensure that by 2050 , half of the demand for gas is met by renewable gas (e.g. biogas) and hydrogen

\footnotetext{
3 The Water Advisory Body was established in June 2018 to advise the minister on measures needed to improve the transparency and accountability of Irish Water.
} 
with the balance accounted for by natural gas. Overall, the company aims for Ireland's gas network to be net zero carbon by 2050 . In December 2019 the group raised a five-year $€ 300$ million bond on the Eurobond market at a coupon rate of 0.125 per cent with a 0.164 per cent yield. Proceeds from the bond were used to repay existing debt and will fund continuing investment in the gas network infrastructure. At the end of 2019 borrowings and other debt stood at $€ 1.15$ billion (€0.745 billion in 2018).

\section{Coillte}

Despite facing significant uncertainty around Brexit and strong downward pressure on a number of product categories, Coillte delivered its second-best financial performance ever. It generated EBITDA (earnings before interest, taxes, depreciation and amortisation) of $€ 103$ million (compared to a record level of $€ 115$ million in 2018) and recorded operating profits before exceptional items of over $€ 63$ million (2018: €71.5 million). Having reduced its net debt following the sale of stakes in four separate wind farms in 2018, the Coillte Group reported a positive net debt balance for the first time ever in 2019. Coillte also paid a dividend of $€ 13$ million to the Exchequer in 2019, bringing the total dividend paid by Coillte over the past three years to $€ 36$ million.

In July 2019 the company established a new not-for-profit subsidiary, Coillte Nature, which will focus on generating social dividends through the conversion of some commercial Coillte forests to recreational forests, as well as the delivery of new woodlands. It also aims to deliver projects that enhance biodiversity and to convert urban forests. Another important development was the conclusion of negotiations with the ESB in relation to a new $€ 100$ million joint venture focused on renewable energy. The stated ambition is to contribute up to $1 \mathrm{GW}$ of new onshore wind energy by 2030. Progress on finalising this joint venture slowed down in December 2020 when the Competition and Consumer Protection Commission announced the decision to carry out a full Phase 2 investigation into the proposed joint venture. The other major uncertainty faced by Coillte in 2021 concerns the impact of Brexit on its core UK market.

\section{Irish Aviation Authority}

The Irish Aviation Authority (IAA) is responsible for civil aviation safety regulation, aviation security, air traffic management and 
commercial activities. The company, which employs over 700 people, reported revenues of $€ 197.2$ million for 2019 (2018: $€ 198.9$ million) and operating profits of $€ 31.9$ million (2018: $€ 31.3$ million). It maintained its ranking of second in Europe for effective implementation of the safety standards of the International Civil Aviation Organisation. Significant developments in 2019 included the completion of a new $€ 27$ million air traffic control tower at Dublin airport. In addition, the IAA continued to prepare for significant regulatory changes, which will include the separation of its air traffic control services from its safety regulation functions as well as taking over the economic functions of the CAR.

Both Brexit and the Covid-19 pandemic will significantly affect the activities and performance of the company. One indicator of the impact of Brexit has been increased applications to the IAA from UKbased individuals and organisations. The number of commercial and general pilot licences issued by the IAA increased by 15.9 per cent while engineer licences increased by 42.1 per cent. As the wider aviation sector is facing its single greatest challenge caused by the Covid-19 global pandemic, the IAA experienced a sharp reduction in revenues in 2020. In June 2020 it announced an agreement with trade unions for planned cost-containment measures against a backdrop of air traffic decreasing by more than 80 per cent since March 2020 . Along with the DAA, the IAA is one of the SOEs most vulnerable to the impact of the pandemic, and the extent to which it can recover in 2021 depends on how quickly international air traffic volumes rebound over the course of the year.

\section{References}

Gleeson, C. (2020, 14 September). Bord na Móna windfarms worth $€ 170 \mathrm{~m}$ secure capacity in state auction scheme. The Irish Times.

Hancock, C. (2021, 6 January). An Post plans $€ 100 \mathrm{~m}$ investment in response to booming parcel business. The Irish Times.

O'Halloran, B. (2020, 30 October). Airports group DAA borrows $€ 500 \mathrm{~m}$ as passenger numbers plunge. The Irish Times.

Palcic, D., \& Reeves, E. (2018). State-owned enterprise sector, 2017. Administration, 66 (1), 59-68.

Palcic, D., \& Reeves, E. (2019). State-owned enterprise sector, 2018. Administration, 67 (1), 51-8.

Palcic, D., \& Reeves, E. (2020). State-owned enterprise sector, 2019. Administration, 68 (1), 67-79. 
Parliamentary Budget Office. (2020). Covid-19 and state-owned companies in the Irish transport sector. PBO publication 33 of 2020. Retrieved from https://data.oireachtas.ie/ie/oireachtas/parliamentaryBudgetOffice/2020/20 20-05-29_covid-19-and-state-owned-companies-in-the-irish-transportsector_en.pdf [10 January 2021].

Wall, M. (2020, 6 April). An Post to begin free coronavirus 'check-in' on vulnerable persons. The Irish Times.

Water Advisory Board. (2020). Quarterly report no. 2 of 2020. Retrieved from https://wateradvisorybody.ie/wp-content/uploads/2020/09/WAB-QuarterlyReport-2-2020-Final.pdf [10 January 2021]. 